Ks. Jerzy Adamczyk

Wyższe Seminarium Duchowne w Radomiu

ORCID 0000-0003-1415-7378

\title{
Normy komplementarne do Kodeksu prawa kanonicznego z 1983 r. w sprawach małżeńskich Konferencji Episkopatów Stanów Zjednoczonych i Kanady
}

Treść: Wstęp. 1. Zaręczyny (kan. $1062 \$ 1$ norma obligatoryjna). 2. Wydanie norm dotyczących egzaminu narzeczonych, zapowiedzi przedmałżeńskich oraz innych odpowiednich środków do przeprowadzenia badań przed zawarciem małżeństwa (kan. 1067 norma obligatoryjna). 3. Określenie sposobu składania tzw. rękojmi wymaganych od strony katolickiej przy zawieraniu małżeństw mieszanych, jak również sposobu ich stwierdzenia w zakresie zewnętrznym i powiadomienia o tym strony niekatolickiej (kan. 1126 norma obligatoryjna). 4. Wiek do małżeństwa (kan. 1083 $\$ 2$ norma fakultatywna). 5. Wydanie własnego obrzędu zawarcia małżeństwa (kan. 1202 norma fakultatywna). 6. Określenie sposobu dokonywania zapisu małżeństwa w księdze zaślubionych (kan. $1121 \S 1$ norma fakultatywna). 7. Wydanie norm w sprawie udzielania dyspensy od formy zawarcia małżeństwa (kan. $1127 \$ 2$ norma fakultatywna). Wnioski.

\section{Wstęp}

W funkcjonowaniu konferencji episkopatu ważną kwestią jest podejmowanie uchwał, zwłaszcza formalnych zarządzeń, które przybierają charakter obowiązujących ustaw. Otóż prawodawca kodeksowy postanawia, iż konferencja biskupów może wydawać dekrety ogólne (ustawy) i dekrety ogólne wykonawcze jedynie w tych sprawach, w których przewiduje to prawo powszechne, bądź szczegółowe 
polecenie Stolicy Apostolskiej, wydane przez nią z własnej inicjatywy lub na prośbę samej konferencji ${ }^{1}$. Uchwały, o których mowa, są jednak ważnie podejmowane na zebraniu plenarnym, gdy opowie się za nimi przynajmniej dwie trzecie biskupów należących do konferencji z głosem decydującym. Otrzymują zaś moc obowiązującą dopiero po zaaprobowaniu ich przez Stolicę Apostolską, z chwilą prawnej ich promulgacji; jej sposób oraz czas wejścia dekretów w życie określa sama konferencja episkopatu².

Tak więc konferencja biskupów posiada - w granicach określonych w KPK - władzę ustawodawczą. Jest to władza zwyczajna a nie delegowana przez prawo, wynikająca z samego urzędu, jakim jest konferencja ${ }^{3}$.

Kodeks prawa kanonicznego z 1983 r. zobowiązuje konferencje biskupie do wydania norm komplementarnych do KPK m. in. w sprawach małżeńskich. Niektóre z tych norm kodeksowych obligują konferencje do wydania stosownych przepisów (kompetencyjne normy obligatoryjne) inne zezwalają na emanację takich postanowień (kompetencyjne normy fakultatywne $)^{4}$. Należy jednak stwierdzić, że z samych sformułowań wielu kanonów kodeksowych wspominających o ustaleniu odnośnych norm prawnych przez konferencję episkopatu nie wynika jednoznacznie, że tego rodzaju normy konferencja jest obowiązana wydać, czy tylko może je promulgowaćs. Być może ten

1 Codex Iuris Canonici auctoritate Ioannis Pauli PP. II promulgatus, Acta Apostolicae Sedis 75 (1983), pars II, s. 1-317. Tekst polski Kodeks Prawa Kanonicznego, przekład polski zatwierdzony przez Konferencję Episkopatu, Poznań 1984, kan. 455 $\$ 1$, (odtąd: KPK).

2 Kan. $455 \$ 2-3$. W. Góralski, Lud Boży. Kościelne prawo osobowe, Częstochowa 1996, s. 217.

3 TAMŻE, s. 217-218.

4 Wiele $\mathrm{z}$ tych kompetencji ma swoje źródło w dekretach ostatniego soboru lub w jego dokumentach aplikujących te uchwały. Aby uzyskać powyższe informacje zob. Codex Iuris Canonici Fontium annotatione, Città del Vaticano 1989.

5 Por. J. MArtín De Agar, Estudio comparado de los decretos generales de las conferencias episcopales, Ius Canonicum 32 (1992), nr 63, s. 176; W. GóRALski, Władza ustawodawcza Konferencji Episkopatu według Kodeksu Prawa Kanonicznego $z 1983$ r., Prawo Kanoniczne 32 (1989), nr 1-2, s. 51-52. 
właśnie wzgląd zadecydował, iż Sekretarz Stanu kard. A. Casaroli, w dniu 8 XI 1983 r., a więc gdy upływał okres vacatio legis nowego Kodeksu, skierował specjalne pismo do przewodniczących konferencji episkopatu, w którym zwrócił się - w imieniu papieża - o szybkie wypracowanie przez wspomniane konferencje norm prawnych, przynajmniej doraźnych, dołączając odrębne wykazy spraw, w których konferencje biskupie obowiązane są, bądź tylko mogą wydać owe normy, stosownie do ustaleń $\mathrm{KPK}^{6}$.

Powstaje zatem kwestia: jak zadanie postawione przed konferencjami biskupimi przez prawodawcę kodeksowego w zakresie wydania norm komplementarnych o małżeństwie wypełniły Konferencje Episkopatów Stanów Zjednoczonych i Kanady? Czy należycie wykorzystały uprawnienia fakultatywne udzielone im przez Kodeks? Czy dostosowały swoje dekrety do miejscowych warunków. Zasygnalizowanym problemom zostanie poświęcony niniejszy artykuł?

\section{Zaręczyny (kan. $1062 \$ 1$ norma obligatoryjna)}

Według kan. $1062 \$ 1$ przyrzeczenie małżeństwa, bądź jednostronne, bądź dwustronne, nazywane zaręczynami, jest regulowane prawem partykularnym, ustanowionym przez konferencję episkopatu z uwzględnieniem zwyczajów oraz prawa świeckiego, gdy takie zostało wydane. Zadanie i obowiązek uregulowania zaręczyn prawodawca

6 A. Casaroli, (Secretairerie d'Etat), Ai presidenti delle Conferenze Episcopali, Communicationes 15 (1983), nr 2, s. 135-139, (dalej: A. CASARoli, Ai presidenti); W. Góralski, Władza ustawodawcza Konferencji Episkopatu, s. 51-52; por. J. Martín de AgAR, Estudio comparado de los decretos generales, s. 176-177. Inną klasyfikację, która rozróżnia kompetencje normatywne, kompetencje administracyjne i akty prawne władzy sądowniczej konferencji biskupów podaje W. AyMANs, Wesensverständnis und Zuständigkeiten der Bischofskonferenz im Codex Iuris Canonici von 1983, Archiv für katholisches Kirchenrecht 152 (1983) s. 46-61.

7 W niniejszym artykule omawiane będą wyłącznie kompetencje legislacyjne konferencji episkopatu w sprawach małżeńskich udzielone przez KPK z 1983 r. w kanonach zamieszczonych w księdze IV, tytule VII: Małżeństwo. Nie będą natomiast poruszane kwestie procesów małżeńskich. 
powszechny pozostawia prawu partykularnemu, które ma być uchwalone przez konferencje biskupie dla ich własnych terytoriów.

Konferencja Biskupów Stanów Zjednoczonych wydała dekret, gdzie zapisano: „Narodowa Konferencja Biskupów Katolickich Stanów Zjednoczonych nie zamierza wydać żadnych norm dotyczących przyrzeczenia małżeństwa, jak wspomniano w kanonie $1062 \$ 1$, jednak bez uszczerbku dla przepisów kanonu $1062 \$ 2$ dotyczących powództwa o naprawienie szkody". Postanowienie podjęto w dniu 18 listopada 1998 r. Uzyskano recognitio Kongregacji Biskupów zgodnie $\mathrm{z}$ art. 82 Konstytucji Apostolskiej Pastor Bonus, która wydała stosowny dekret 29 września 1999 r. $^{8}$

W Kanadzie (gdzie biskupi nie wydali żadnych norm w sprawie zaręczyn) i Stanach Zjednoczonych nie ma zwyczaju zawierania zaręczyn kanonicznych. W związku z tym kan. 1062 ma niewielkie znaczenie praktyczne w tych krajach ${ }^{9}$. Wydaje się, że Konferencja Episkopatu Kanady powinna jednak wydać, na wzór Konferencji Biskupów Stanów Zjednoczonych normę, gdzie komunikuje się, że nie zamierza się wydać żadnych norm dotyczących przyrzeczenia małżeństwa, o których traktuje kan. $1062 \$ 1$, jednak bez uszczerbku dla przepisów kanonu $1062 \$ 2$ dotyczących powództwa o naprawienie szkody. Byłoby to formalne wykonanie obligatoryjnej normy kodeksowej.

8 United States Conference of Catholic Bishops, Complementary norms, Canon 1062 \& 1 (1 november 1999) (http://www.usccb.org/beliefs-and-teachings/ what-we-believe/canon-law/complementary-norms/canon-1062-1-engagement.cfm, [dostęp 5. 02.2020].

9 Por. J. BeAL, Commentary on canon 1062, w: J. BeAL (red.), New Commentary on the Code of Canon Law, New York 2000, s. 1259. 


\section{Wydanie norm dotyczących egzaminu narzeczonych, zapowiedzi przedmałżeńskich oraz innych odpowiednich środków do przeprowadzenia badań przed zawarciem małżeństwa (kan. 1067 norma obligatoryjna)}

Prawodawca powszechny w kan. 1067 zobowiązuje konferencję episkopatu „wydać normy dotyczące egzaminu narzeczonych, zapowiedzi przedmałżeńskich oraz innych odpowiednich środków do przeprowadzenia badań przed zawarciem małżeństwa, aby proboszcz pilnie ich przestrzegając mógł przystąpić do asystowania przy małżeństwie”.

Biskupi Stanów Zjednoczonych, stosując się do tego przepisu, postanowili, że: „Narodowa Konferencja Biskupów Katolickich, zgodnie z przepisami kan. 1067 i z należytym uwzględnieniem kan. 1068, niniejszym postanawia, że przy przygotowywaniu do małżeństwa należy przestrzegać następujących norm: narzeczeni powinni otrzymać odpowiednią edukację i przygotowanie duszpasterskie poprzez uczestnictwo $\mathrm{w}$ programie przygotowania do małżeństwa zatwierdzonym przez biskupa diecezjalnego; strony powinny zostać przesłuchane, co do ich wolności do zawarcia małżeństwa; ochrzczeni katolicy powinni przedstawić niedawno wydane świadectwo chrztu $\mathrm{z}$ adnotacjami; $\mathrm{w}$ razie potrzeby należy przedstawić dodatkową dokumentację (np. oświadczenia rodziców) potwierdzającą wolność strony katolickiej do zawarcia małżeństwa; ochrzczeni niekatolicy powinni przedstawić odpowiedni dokument potwierdzający chrzest i wolność do zawarcia małżeństwa; osoby nieochrzczone powinny przedstawić stosowny dowód wolności do zawarcia małżeństwa; przygotowanie do małżeństwa powinno być zgodne z zarządzeniami kan. 1063 (odnośnie do tego, co musi poprzedzać małżeństwo) oraz kan. 1064, 1071, $1072,1086 \$ 2$ i 1125, które powierzają pewne sytuacje specjalnej trosce miejscowych ordynariuszy; przygotowanie do małżeństwa powinno być zgodne z odpowiednimi przepisami prawa cywilnego"10.

10 United States Conference of Catholic Bishops, Complementary norms, Canon 1067 (20 October 2000), (http://www.http://www.usccb.org/ 
Należy zauważyć, że chociaż przytoczona norma uzupełniająca biskupów północno-amerykańskich do kan. 1067 podkreśla znaczenie odpowiedniego przygotowania do zawarcia małżeństwa, nie określa jednak ona szczegółowo, w jaki sposób takie przygotowanie powinno dokonywać się. Konferencja pragnie przez to wyraźnie podkreślić, że niektóre obowiązki kanoniczne, opisane w Kodeksie z 1983 r., należą w sposób szczególny do obowiązków ordynariuszy miejsca, a nie do konferencji episkopatu ${ }^{11}$.

Konferencja Episkopatu Kanady w sprawie kanonicznego dochodzenia przedślubnego postanowiła, jak następuje: „zgodnie z przepisami kan. 1067 r., Kanadyjska Konferencja Biskupów Katolickich niniejszym postanawia, że przy przygotowywaniu nupturientów do małżeństwa należy przestrzegać następujących procedur: 1. przed zawarciem małżeństwa należy odpowiednio przygotować się zgodnie z zaleceniami kan. 1063 i diecezjalnymi wytycznymi dotyczącymi duszpasterstwa przedmałżeńskiego. Obowiązkiem właściwego ordynariusza lub właściwego proboszcza jednej ze stron jest upewnienie się, że wymagane przygotowanie zostało należycie zrealizowane i przeprowadzono dochodzenie przedślubne. Jeśli ktoś inny niż proboszcz ma asystować przy zawieraniu małżeństwa, odpowiedzialność za dochodzenie przedślubne może być powierzona tej osobie, która jednak, za pomocą autentycznego dokumentu, ma jak najszybciej poinformować proboszcza o wyniku tego dochodzenia. 2. strony mają być przesłuchiwane osobno, pod przysięgą, szczególnie w odniesieniu do ich wolności obywatelskiej i kanonicznej do zawarcia małżeństwa, rozumienia i akceptowania celów i istotnych przymiotów małżeństwa, a także wszelkich możliwych przeszkód. 3. należy używać formularzy zawierających pytania przedślubne dopuszczonych do stosowania w diecezjach kanadyjskich. Mogą one zostać zachowane w swojej

beliefs-and-teachings/what-we-believe/canon-law/complementary-norms/canon-1067-the-investigation-of-freedom-to-marry.cfm, [dostęp 5.02.2020]; por. F. Gavin, Pastoral Care in Marriage Preparation (Can. 1063). History, Analysis of the Norm and Its Implementation by Some Particular Churches, Roma 2004, s. 162-163. 11 F. Gavin, Pastoral Care in Marriage Preparation (Can. 1063), dz. cyt., s. 163. 
obecnej formie. 4. Dokumentacja przedślubna powinna zawierać standardowe kwestionariusze, świadectwa chrztu i bierzmowania, zgodę rodziców lub opiekunów, jeśli jest to konieczne, zaświadczenie o publikacji zapowiedzi, jeśli zostały one ogłoszone (...), jak również inną stosowną dokumentację. W przypadku małżeństw mieszanych, specjalny formularz zatwierdzony do użytku w Kanadzie jest również wypełniany przez osobę przeprowadzającą badanie i dołączany do akt. 5. Jeśli jedna lub obie strony zamierzające zawrzeć związek małżeński pozostawały wcześniej w związku małżeńskim, dochodzenie przedślubne nie zostanie przeprowadzone do czasu uzyskania uzasadnionej pewności, że poprzedni związek został rozwiązany lub uznany za nieważny. Nie należy wyznaczać daty ślubu, dopóki nie zostanie przedstawiony wymagany dowód stanu wolnego koniecznego do zawarcia związku małżeńskiego i, w razie potrzeby, nie zostaną uzyskane odpowiednie zezwolenia. 6 . W przypadku powtórnego małżeństwa jednej ze stron lub obu, gdy poprzedni związek został uznany za nieważny lub został rozwiązany z przyczyn innych niż śmierć, należy zachować szczególną ostrożność, jeżeli Stolica Apostolska lub trybunał małżeński wydał zakaz zawierania małżeństwa (vetitum) lub monit (monitum ${ }^{12}$ wobec jednej ze stron lub obydwu. W takich przypadkach, przed ustaleniem daty ślubu, należy zasięgnąć opinii ordynariusza miejsca, na którego terenie ma być zawarte małżeństwo, zgodnie z normami ustalonymi w każdej diecezji. Inne sytuacje, które wymagają zezwolenia miejscowego ordynariusza umieszczone są w katalogu w kan. 1071"13.

12 W przypadku gdy w sprawie o nieważność małżeństwa pojawił się np. wątek zaniedbywania potomstwa poprzez niepłacenie alimentów, sąd kościelny może nie poprzez zakaz (vetitum), lecz poprzez monit (monitum) zwrócić uwagę na tę okoliczność duszpasterzowi, który przygotowuje parę do zawarcia związku małżeńskiego. Por. P. KroczeK, Kanoniczne zakazy związane z małżeństwem jako możliwość wsparcia ściagalności alimentów na dzieci, Polonia Sacra 29 (73) (2011), s. 193.

13 Canadian Conference of Catholic Bishops, Complementary norms to the 1983 Code of Canon Law, The prenuptial inquiry, can. 1067, Decree nr 36, Ottawa 1996, dz. cyt., s. 71-73. 
Konferencja Episkopatu Kanady osobny dekret (nr 37) poświęca innej kwestii z kan. 1067, mianowicie głoszeniu zapowiedzi przedmałżeńskich. Biskupi postanawiają: „Zgodnie z postanowieniami kan. 1067 Kanadyjska Konferencja Biskupów Katolickich niniejszym dekretem orzeka: 1. kanoniczna publikacja zapowiedzi małżeństwa nie obowiązuje już w Kanadzie. 2. jeżeli zapowiedzi nie są publikowane, to stan wolny stron do zawarcia małżeństwa wobec Kościoła ustala się w przypadku katolików przez okazanie świadectwa chrztu $\mathrm{z}$ datą krótszą niż sześć miesięcy, a w przypadku niekatolików przez okazanie należycie poświadczonego dokumentu publicznego lub zaprzysiężonego oświadczenia dwóch osób zeznających o ich stanie wolnym do zawarcia małżeństwa. 3. Co więcej, badanie przedślubne, określone w Dekrecie nr 36 Konferencji Biskupów Katolickich Kanady, skupia się również na stanie wolnym stron do zawarcia małżeństwa, ich zrozumieniu i akceptacji celów i istotnych przymiotów małżeństwa oraz na wszelkich możliwych przeszkodach. 4. Zapowiedzi mogą być publikowane lub ogłaszane, jeśli strony tego zażądają lub jeśli zalecają to przepisy diecezjalne"14.

Należy zauważyć, że normy komplementarne Konferencji Episkopatu Kanady są dużo bardziej szczegółowe niż analogiczne przepisy biskupów USA. Jest jasne, że także i w tym przypadku szeroki margines pozostawia się ustawodawstwu diecezjalnemu. Wydaje się, że zrezygnowanie z zapowiedzi przedmałżeńskich na poziomie krajowym nie jest zbyt trafne, choć taka możliwość istnieje na żądanie stron, czy na podstawie prawa diecezjalnego, gdyż pozbawia dochodzenie przedmałżeńskie ważnego kryterium weryfikacji stanu wolnego, czy stwierdzenia innych okoliczności, które mogą mieć wpływ na ważność, czy godziwość przyszłego małżeństwa.

14 TAMżE, s. 77. 
3. Określenie sposobu składania tzw. rękojmi wymaganych od strony katolickiej przy zawieraniu małżeństw mieszanych, jak również sposobu ich stwierdzenia w zakresie zewnętrznym i powiadomienia o tym strony niekatolickiej (kan. 1126 norma obligatoryjna)

Prawodawca kodeksowy w kan. 1126 zarządza, iż „konferencja episkopatu powinna zarówno określić sposób składania tych oświadczeń i przyrzeczeń, które są zawsze wymagane, jak i ustalić, w jaki sposób ma to być stwierdzone w zakresie zewnętrznym oraz jak ma być o tym powiadomiona strona niekatolicka”. Jest to ostatnia z kompetencyjnych norm obligatoryjnych tyczących się małżeństwa w KPK.

Biskupi Stanów Zjednoczonych respektując postanowienia kan. 1126 podjęli następującą decyzję: „partykularne normy wydane przez Narodową Konferencję Biskupów Katolickich 16 listopada 1970 r. będą nadal obowiązywać. Należy je przejrzeć i dopracować, a następnie ponownie opublikować, aby uniknąć dwuznaczności lub wątpliwości dotyczących małżeństw mieszanych"15. Biskupi w przytoczonej normie odwołują się do „Oświadczenia w sprawie realizacji Listu apostolskiego Matrimonia mixta” z 1 stycznia 1971 r. Konferencji Biskupów Katolickich Stanów Zjednoczonych, gdzie zapisano: „Deklaracja i obietnica złożona przez katolika, konieczne do zwolnienia z przeszkody w zawarciu małżeństwa mieszanego (różnicy religii lub różnicy wyznania), powinny być złożone w następujących słowach lub w ich istotowym równoważniku: «Potwierdzam swoją wiarę w Jezusa Chrystusa i z Bożą pomocą zamierzam nadal żyć tą wiarą w Kościele katolickim» oraz «Obiecuję, że uczynię wszystko, co w mojej mocy, aby dzielić się wiarą, którą otrzymałem z naszymi dziećmi, chrzcząc je i wychowując jako katolików». Deklaracja i obietnica są składane w obecności kapłana lub diakona ustnie lub pisemnie, zgodnie z wolą

\footnotetext{
15 United States Conference of Catholic Bishops, Complementary norms, Canon 1126 (21 October 1983), http://www.usccb.org/beliefs-and-teachings/what-we-believe/canon-law/complementary-norms/canon-1126-declarations-and-promises-mixed-marriages.cfm, [dostęp 5.02.2020].
} 
katolika. Forma deklaracji i obietnicy nie ulega zmianie w przypadku małżeństwa katolika $\mathrm{z}$ innym ochrzczonym chrześcijaninem, ale kapłan powinien zwrócić uwagę katolika na komunię korzyści duchowych w takim chrześcijańskim małżeństwie. Obietnica i deklaracja powinny być złożone w świetle "pewnej, choć niedoskonałej, komunii» niekatolika z Kościołem katolickim ze względu na wiarę w Chrystusa i chrzest. W stosownym czasie przed ślubem, najlepiej w ramach zwykłych pouczeń przedmałżeńskich, niekatolicy muszą być poinformowani o obietnicach i odpowiedzialności strony katolickiej. Nie jest przewidziany żaden dokładny tryb ani sposób informowania niekatolika. Może to zrobić kapłan, diakon lub strona katolicka. Nie jest wymagane żadne formalne oświadczenie strony niekatolickiej. Ale wcześniejsze wzajemne zrozumienie tej kwestii powinno zapobiec ewentualnej dysharmonii, która mogłaby powstać podczas życia małżeńskiego. Kapłan, który składa wniosek o dyspensę od przeszkody w zawarciu małżeństwa mieszanego, zaświadcza, że oświadczenie i obietnica zostały złożone przez katolika i że strona niekatolicka została poinformowana o tym wymogu. Dokonuje się tego w następujących lub podobnych słowach: «Wymagana obietnica i deklaracja zostały złożone przez katolika w mojej obecności. Niekatolik został poinformowany o tym wymogu, aby mieć pewność, że jest on (ona) świadomy obietnicy i obowiązku ze strony katolika. Obietnica katolika ma być złożona szczerze, i należy domniemywać, że jest złożona prawdziwie. Jeżeli jednak kapłan ma powody, by wątpić w szczerość obietnicy złożonej przez katolika, nie może przedstawiać prośby o dyspensę i powinien przedłożyć sprawę miejscowemu ordynariuszowi”"16.

Konferencja biskupów kanadyjskich stosując się do przepisu kan. 1126 wydała dekret, gdzie zawarte są następujące normy: „Zgodnie z zaleceniami kan. 1125 i 1126 Kodeksu prawa kanonicznego dotyczących deklaracji i obietnic wymaganych od strony katolickiej w celu uzyskania zgody miejscowego ordynariusza na zawarcie małżeństwa

16 National Conference of Catholic Bishops, Statement on the Implementation of the Apostolic Letter on Mixed Marriages (1 january 1971), nr 5-9, https:// www.catholicdoors.com/misc/marriage/nccb.htm, [dostęp 5.02.2020]. 
mieszanego, Konferencja Biskupów Katolickich Kanady wydaje następujący dekret: 1. strona katolicka musi najpierw oświadczyć, że jest gotowa usunąć niebezpieczeństwo porzucenia wiary katolickiej (zob. kan. 1125, n. 1); 2. strona katolicka, po przedyskutowaniu tej sprawy z drugą stroną, ma także złożyć szczerą obietnicę, że uczyni wszystko, co w jej mocy, aby dzieci z ich małżeństwa zostały ochrzczone i wychowane w Kościele katolickim (zob. kan. 1125, n. 1); 3. wymagane od strony katolickiej przyrzeczenia powinny być składane ustnie w obecności proboszcza lub jego delegata, który prowadzi dochodzenie przedślubne; obecność świadków nie jest konieczna. Strona niekatolicka powinna być odpowiednio wcześnie poinformowana o tych obietnicach oraz o zobowiązaniach strony katolickiej (zob. kan. 1125, n. 2) 4. w celu uzyskania zezwolenia do zawarcia małżeństwa, proboszcz parafii strony katolickiej lub jego zastępca powinien zapewnić miejscowego ordynariusza na piśmie, że obietnice zostały złożone, i że strona niekatolicka została odpowiednio poinformowana (zob. kan. 1126); 5. zawarcie małżeństwa mieszanego nie może być dozwolone w przypadkach, w których jest oczywiste, że strona katolicka nie jest szczera w składaniu obietnic lub odmawia ich złożenia (por. kan. 1125); 6. te same obietnice muszą być złożone przez stronę katolicką, gdy partner nie jest chrześcijaninem lub nie jest wyznawcą żadnej religii, przed udzieleniem dyspensy, która jest wymagana dla ważności małżeństwa (zob. kan. 1086 \$2)"17.

Trzeba zauważyć, że ponieważ normy Kodeksu regulującego małżeństwa mieszane są zasadniczo takie same jak normy Matrimonia mixta, wiele konferencji episkopatu, w tym amerykańska i kanadyjska, po ogłoszeniu zrewidowanego Kodeksu, po prostu powtórzyło przepisy, które wydały w odpowiedzi na Matrimonia mixta ${ }^{18}$.

\footnotetext{
17 Canadian Conference of Catholic Bishops, Complementary norms to the 1983 Code of Canon Law, In view of a mixed marriage, can. 1126, Decree $n r$ 34, Ottawa 1996, dz. cyt., s. 87.

18 J. BeAL, Commentary on canon 1126, w: J. BeAL (red.), New Commentary on the Code of Canon Law, New York 2000, s. 1347-1348; por. J. MARTín DE AgAR, Estudio comparado de los decretos generales, dz. cyt., s. 217-218.
} 
Wydaje się, że zawarta w nr 3 Dekretu nr 34 biskupów kanadyjskich norma, według której przyrzeczenia strony katolickiej mają być składane ustnie w obecności proboszcza lub jego delegata, który prowadzi dochodzenie przedślubne, bez koniecznej obecności świadków nie jest najszczęśliwsza, gdyż winny być one składane na piśmie, w celu późniejszego ich udowodnienia.

\section{Wiek do małżeństwa (kan. $1083 \$ 2$ norma fakultatywna)}

Według kan. $1083 \$ 2$ konferencja episkopatu ma prawo ustalić wyższy wiek do godziwego zawarcia małżeństwa. Kan. 1083 \$1 określa minimalny wiek do ważnego zawarcia małżeństwa, ale w $\$ 2$ tego samego kanonu pozostawia konferencji biskupów możliwość ustalenia wyższego wieku dla jego legalności (godziwości).

$\mathrm{Z}$ jednej strony kwestia ta nie stwarza większych trudności w nauce, ale w swej istocie dotyka ius connubii wiernych, które będąc prawem naturalnym, może podlegać ograniczeniom tylko z poważnej przyczyny odnośnie do jego ważnego i godziwego wykonywania. Jest to kwestia, która została również poruszona przez większość konferencji episkopatu w dekretach dotyczących uzupełniających norm kodeksowych. Konferencje podają różny minimalny wiek do małżeństwa. Od tego ustalonego w KPK (14 lat dla kobiet i 16 dla mężczyzn), do 18 i 20 lat. Niektóre konferencje, biorąc pod uwagę zawarty w kan. $1071 \S 1$ n. 2 zakaz zawierania małżeństw, które nie mogą być uznane lub zawarte według prawa państwowego, przystosowały wiek wymagany dla obu stron do prawa cywilnego ${ }^{19}$.

Jeśli konferencja episkopatu jakiegoś narodu lub regionu skorzysta $\mathrm{z}$ tego kan. $1083 \$ 2$, może zostać ustalona korzystna równowaga między uniwersalną normą, a miejscowymi potrzebami. To prawda, że konferencja nie może wprowadzić przeszkody uniezdalniającej, ale w praktyce jej decyzje uniemożliwiłyby zawarcie małżeństwa, przynajmniej na jej terytorium, ponieważ nie można by asystować przy

19 Por. J. Martín de Agar, Estudio comparado de los decretos generales, dz. cyt., s. $216-217$. 
małżeństwach tych, którzy są młodsi niż wymagany wiek ustalony przez tę konferencję ${ }^{20}$.

Konferencja Episkopatu Stanów Zjednoczonych nie odniosła się do kan. $1083 \$ 2$ i konsekwentnie nie wydała norm odnośnie do wieku godziwego zawarcia małżeństwa i nie odniosła się w tej kwestii do prawa państwowego. Stąd zarówno do ważności, jak i do godziwości w USA obowiązują normy kodeksowe.

Konferencja Episkopatu Kanady wykorzystując normę kompetencyjna zawartą w kan. $1083 \$ 2$ postanowiła: „Zgodnie z przepisem kan. $1083 \$ 2$, Kanadyjska Konferencja Biskupów Katolickich niniejszym postanawia, że minimalny wiek pozwalający na legalne zawarcie małżeństwa przed Kościołem Katolickim w Kanadzie wynosi osiemnaście lat dla obu stron. W szczególnych przypadkach, miejscowy ordynariusz może dyspensować od niniejszego dekretu po konsultacji z proboszczem (proboszczami) stron lub strony katolickiej (por. kan. 88)"21.

\section{Wydanie własnego obrzędu zawarcia małżeństwa (kan. 1202 norma fakultatywna)}

Wydanie własnego obrzędu zawarcia małżeństwa jest następną kompetencją konferencji episkopatu w dziedzinie małżeństwa. Owa kompetencja dotyczy liturgicznej formy małżeństwa, która obejmuje formę prawną wyrażenia i przyjęcia zgody ${ }^{22}$. Według kan. 1120 „konferencja episkopatu może opracować własny obrzęd zawierania małżeństwa, wymagający zatwierdzenia przez Stolicę Świętą, odpowiadający miejscowym i ludowym zwyczajom, przystosowanym do ducha chrześcijańskiego, z zachowaniem jednak prawa, by asystujący,

\footnotetext{
20 L. Örsy, Marriage in canon law. Texts and Comments Reflections and Questions, Dublin 1988, s. 106.

21 Canadian Conference of Catholic Bishops, Complementary norms to the 1983 Code of Canon Law, Minimum age for marriage, can. 1083 \$ 2, Decree nr 12, Ottawa 1996, s. 81.

22 Por. J. Martín de Agar, Estudio comparado de los decretos generales, dz. cyt., s. 217.
} 
obecny przy zawieraniu małżeństwa, zapytał nupturientów, czy wyrażają zgodę i tę zgodę przyjął”.

Kanon 1120 upoważnia konferencje episkopatu do „opracowania własnego obrzędu dostosowanego do miejscowych i narodowych zwyczajów"23. Liturgiczna rola konferencji biskupich nie ogranicza się do przygotowywania i opublikowania w języku narodowym wersji wydań typicznych rytuału małżeństwa ${ }^{24}$. Mogą one również przygotowywać własne obrzędy małżeństwa, które uwzględniają i dostosowują zwyczaje i praktyki swoich kultur w duchu chrześcijańskim.

Kanon 1120 zawiera normę kompetencyjną liturgiczną i fakultatywną, którą nie zawsze można było niezwłocznie zastosować. Ponadto w wielu miejscach istnieją już odpowiednie rytuały małżeńskie. Z tego powodu większość konferencji episkopatu nie skorzystała z tej kompetencji, a te, które wspominają o niej, czynią to, aby podkreślić rezygnację z tego uprawnienia lub, aby odwołać się do rytuałów już opracowanych przez samą konferencję, albo co najwyżej, aby ukazać podstawę prawną do powierzenia jakiemuś organowi opracowania i propozycji własnego rytuału małżeństwa ${ }^{25}$. Konferencje Episkopatów Stanów Zjednoczonych i Kanady nie biorą pod uwagę normy kan. $1083 \S 1$.

23 Concilium Oecumenicum Vaticanum II, Constitutio de sacra Liturgia: Sacrosanctum Concilium (4 Decembris 1963), nr 77, Acta Apostolicae Sedis, 56 (1964), s. 97-138. Tekst polski: SobóR WATY KAŃski II, Konstytucja o liturgii świętej Sacrosanctum Concilium, w: Sobór Watykański II. Konstytucje, dekrety, deklaracje. Tekst polski: Nowe tłumaczenie, Poznań 2002, s. 48-78.

${ }^{24}$ Kan. $838 \$ 3 \mathrm{KPK}$ : „Do konferencji biskupów należy wierne przygotowywanie tłumaczeń ksiąg liturgicznych na języki narodowe, po dokonaniu odpowiednich akomodacji w określonych granicach (...) po potwierdzeniu przez Stolicę Świętą". 25 Por. J. Martín de AgAr, Estudio comparado de los decretos generales, dz. cyt., s. 217. 


\section{Określenie sposobu dokonywania zapisu małżeństwa w księdze zaślubionych (kan. 1121 \$ 1 norma fakultatywna)}

Prawodawca powszechny w kan. $1121 \S 1$ stwierdza, że określa sposób dokonywania zapisu małżeństwa w księdze zaślubionych: „Po zawarciu małżeństwa, proboszcz miejsca zawarcia lub jego zastępca, chociażby żaden $\mathrm{z}$ nich przy nim nie asystował, powinien jak najszybciej zapisać w księdze zaślubionych nazwiska małżonków, osoby asystującej i świadków, a także miejsce i datę zawarcia małżeństwa, w sposób określony przez Konferencję Episkopatu lub przez biskupa diecezjalnego".

Kanon zawiera normę fakultatywną, która upoważnia konferencje biskupie do określenia sposobu dokonywania zapisu małżeństwa w księdze zaślubionych. Uważna lektura norm kompetencyjnych z łatwością pozwala stwierdzić, że obie występujące w tym artykule konferencje pomijają milczeniem te kwestię. Stąd należy skonstatować, że w tej sprawie obowiązują w każdej diecezji jej własne przepisy.

\section{Wydanie norm w sprawie udzielania dyspensy od formy zawarcia małżeństwa (kan. $1127 \$ 2$ norma fakultatywna)}

Ostatnią z fakultatywnych norm kompetencyjnych w zakresie sakramentu małżeństwa jest możliwość wydania przepisów przez konferencję episkopatu w sprawie udzielania dyspensy od formy zawarcia małżeństwa, o czym prawodawca mówi w kan. $1127 \$ 2$, którego brzmienie jest następujące: „Jeśli poważne trudności nie pozwalają zachować formy kanonicznej, ordynariusz miejsca strony katolickiej ma prawo dyspensować od niej w poszczególnych przypadkach, po poradzeniu się jednak ordynariusza miejsca zawarcia małżeństwa, z zachowaniem - i to do ważności - jakiejś publicznej formy zawarcia. Do konferencji episkopatu należy określić normy, według których byłaby udzielana dyspensa w jednolity sposób”.

Kan. 1127 podaje zasady dotyczące obowiązku zachowania formy kanonicznej (kan. 1108) przy zawieraniu małżeństw mieszanych $\mathrm{z}$ jednej strony dla zapewnienia wolności religijnej, a z drugiej - dla 
uznania ważności sakramentu małżeństwa w Kościołach wschodnich niekatolickich. Jeśli chodzi o małżeństwo strony katolickiej ze stroną niekatolicką - z wyjątkiem małżeństwa ze stroną należącą do Kościoła wschodniego, tzn. prawosławnego - należy zachować formę przewidzianą w kan. 1108. Natomiast w przypadku małżeństwa strony katolickiej ze stroną prawosławną, to forma kanoniczna obowiązuje tylko do godziwości. Do ważności wymagany jest tylko udział świadka urzędowego katolickiego (biskup, kapłan, diakon, por. kan. $207 \$ 1 ; 1008 ; 1009 \$ 1$ ) lub niekatolickiego, bez świadków zwykłych. Nie wystarcza obecność bierna świadka urzędowego, dlatego że norma prawna wymaga jego ,interwencji”, tzn. aktywności. Ponadto Kościoły wschodnie niekatolickie wymagają do ważności nie tylko obecności kapłana, lecz także jego błogosławieństwa. Zakazana jest obecność symultaniczna szafarza katolickiego i niekatolickiego, jak również sukcesywna celebracja małżeństwa wobec szafarza niekatolickiego dla powtórzenia lub odnowy zgody. Ordynariusz miejscowy strony katolickiej może ważnie udzielić dyspensy od obowiązku zachowania formy kanonicznej, jeżeli zaistnieją poważne motywy bądź poważne trudności związane z zachowaniem formy kanonicznej (kan. $90 \$ 1$ ) po wysłuchaniu opinii (kan. $127 \$ 2$, n. 2) ordynariusza miejscowego, na którego terytorium będzie zawierane małżeństwo bez formy kanonicznej, w celu zapobieżenia zgorszeniu. Mimo udzielonej dyspensy od formy kanonicznej do ważności małżeństwa mieszanego strony powinny zachować jakąś formę publiczną zawarcia małżeństwa, czyli społecznie uznawaną bądź religijną, bądź świecką, tzn. ustawową bądź zwyczajową. Normy szczegółowe dotyczące udzielania dyspensy od formy zawarcia małżeństwa mieszanego wydają konferencje biskupów ${ }^{26}$.

26 W. Góralski, Komentarz do kan. 1127, w: J. Krukowski (red.), Komentarz do Kodeksu Prawa Kanonicznego. t. III. 2. Ks. IV. Uświęcające zadanie Kościoła, Poznań 2011, s. 334-335. Powodem konsultacji obu ordynariuszy miejsca wymienionych w kan. $1127 \$ 2$ jest fakt, że to miejscowy ordynariusz, na którego terytorium małżeństwo mieszane faktycznie jest zawierane, wie lub łatwiej może posiąść wiedzę o tym, czy zawarcie kanonicznego małżeństwa w formie niekanonicznej niesie ze sobą ryzyko zgorszenia lub innych niedogodności, których należy unikać. 
Konferencja Episkopatu Stanów Zjednoczonych wykorzystując przytoczoną możliwość z kan. $1127 \$ 2$ postanowiła, że „partykularne normy wydane przez Krajową Konferencję Biskupów Katolickich 16 listopada $1970 \mathrm{r}$. pozostają w mocy, z wyjątkiem tego, że ordynariusz miejsca, $w$ którym sakrament małżeństwa ma się dokonać, nie jest już uprawniony do udzielania dyspensy od formy małżeństwa" ${ }^{27}$.

Konferencja Biskupów Katolickich Stanów Zjednoczonych w przytoczonej normie uzupełniającej nawiązuje do wydanego przez siebie „Oświadczenia w sprawie realizacji Listu apostolskiego w sprawie małżeństw mieszanych" z 1 stycznia 1971 r. gdzie wtedy postanowiono: „Tam, gdzie istnieją poważne trudności w zachowaniu katolickiej formy kanonicznej w małżeństwie mieszanym, miejscowy ordynariusz strony katolickiej lub miejsca, w którym małżeństwo ma się dokonać, może dyspensować katolika $\mathrm{z}$ obowiązku zachowania formy z powodu słusznej przyczyny duszpasterskiej. Wyczerpujący wykaz przyczyn jest niemożliwy do przedstawienia, ale są następujące rodzaje przyczyn: osiągnięcie zgody w rodzinie lub uniknięcie wyobcowania z rodziny, uzyskanie zgody rodziców na małżeństwo, uznanie szczególnej relacji między stronami, lub szczególnej przyjaźni z niekatolickim ministrem, pozwolenie na zawarcie małżeństwa w kościele, który ma szczególne znaczenie dla osób niekatolickich. Jeśli ordynariusz strony katolickiej udzieli dyspensy do zawarcia małżeństwa mieszanego, które ma być celebrowane w innej diecezji, należy wcześniej poinformować o tym ordynariusza tamtej diecezji.

W każdym przypadku ordynariusz miejsca musi wskazać w momencie udzielania dyspensy konkretną formę publiczną, w której małżeństwo ma być zawarte, dla jego ważności. Wydaje się, że może on określić jakąś formę publiczną inną niż te wskazane przez konferencję episkopatu, ponieważ kan. 1127 nie ogranicza możliwości ordynariusza w tej kwestii, pod warunkiem, że faktycznie wskaże on formę publiczną, która jest wymagana ad validitatem. R. NAVARro VALLs, La forma juridica del matrimonio, Revista Española de Derecho Canónico, 39 (1983), nr 114, s. 507.

27 United States Conference of Catholic Bishops, Complementary norms, Canon $1127 \$ 2$ (1 October 1983), http://www.usccb.org/beliefs-and-teachings/what-we-believe/canon-law/complementary-norms/canon-1126-declarations-and-promises-mixed-marriages.cfm, [dostęp 5.02.2020]. 
Zazwyczaj dyspensa od formy kanonicznej jest udzielana w związku z planowaną formą religijnej celebracji małżeństwa. W niektórych wyjątkowych okolicznościach (np. w przypadku niektórych małżeństw katolicko-żydowskich) może być konieczne udzielenie dyspensy, aby można było przeprowadzić ceremonię cywilną. W każdym razie wymagana jest forma publiczna, która jest cywilnie uznawana do zawarcia małżeństwa" 28 .

Jest zrozumiałe, że biskupi Stanów Zjednoczonych, zmieniając nieco normę z 1970 r., która dopuszczała, aby także ordynariusz miejsca zawarcia małżeństwa mieszanego mógł zwolnić stronę katolicką od obowiązku zachowania formy kanonicznej (obecnie według norm komplementarnych tejże konferencji nie ma prawa tego czynić), dostosowali się do prawa powszechnego, które dyspensę od formy kanonicznej dla strony katolickiej zastrzega wyłącznie ordynariuszowi miejsca katolika. Wydaje się słuszne, że biskupi zachowali wcześniejsze normy odnośnie do małżeństw mieszanych w kwestii dyspensy od formy kanonicznej, gdyż one zasadniczo zgadzają się z normami kodeksowymi w tej materii ${ }^{29}$.

Odnośnie do Kanady to dekret nr 13 Kanadyjskiej Konferencji Biskupów Katolickich stwierdza, jak następuje: „Zgodnie z przepisem kan. $1127 \$ 2$, Kanadyjska Konferencja Biskupów Katolickich niniejszym zarządza, co następuje: 1. ważne są tylko te małżeństwa, które zostały zawarte w obecności miejscowego ordynariusza lub proboszcza, lub kapłana, diakona lub osoby świeckiej należycie delegowanej, która w obecności dwóch świadków asystuje zgodnie z normami kanonicznymi, z zastrzeżeniem wyjątków przewidzianych w prawie (por. kan. 1108); 2. przed zawarciem małżeństwa należy ustalić, że nic nie stoi na przeszkodzie do jego ważnego i godziwego zawarcia (por.

\footnotetext{
28 National Conference of Catholic Bishops, Statement on the Implementation of the Apostolic Letter on Mixed Marriages, nr 10-11.

29 Por. J. Huels, Empowerment for Ministry. A Complete Manual on Diocesan Faculties of Priests, Deacons, and Lay Ministers, Mahwah, New Jersey 2003, General Introduction XV-XX, nr 4. 28; por. J. MARTín DE AGAR, Estudio comparado de los decretos generales, dz. cyt., s. 217-218.
} 
kan. 1066); 3. duszpasterze są zobowiązani do zapewnienia należytego przygotowania do małżeństwa (por. kan. 1063); 4. jeśli po okresie przygotowawczym okaże się, że istnieją poważne trudności w zachowaniu formy kanonicznej, miejscowy ordynariusz strony katolickiej ma prawo dyspensować od niej, w indywidualnych przypadkach, po zasięgnięciu opinii ordynariusza miejsca celebracji (por. kan. 1127); 5. powody udzielania dyspensy od formy kanonicznej powinny dotyczyć w jakiś istotny sposób: 1) dobra duchowego stron, zwłaszcza jeśli strona niekatolicka jest przywiązana do wiary rodzinnej; 2) ciszy i spokoju ich osobistych lub rodzinnych relacji; 3) lub opierać się na szczególnej relacji, jaki strona niekatolicka ma z niekatolickim ministrem lub miejscem kultu; 6. jeżeli udzielona jest dyspensa od formy, do ważności wymagana jest publiczna celebracja (kan. 1127 $\$ 2$ ); 7. miejscowy ordynariusz, który udziela dyspensy, musi dopilnować, aby dyspensa i celebracja zostały zapisane w księdze, zarówno kurii, jak i parafii strony katolickiej, której proboszcz (lub delegat) przeprowadził zapytania dotyczące badania dotyczące wolności oraz w księdze chrztów strony katolickiej; 8. współmałżonek katolicki ma obowiązek jak najszybciej powiadomić tego samego ordynariusza i proboszcza parafii o fakcie zawarcia małżeństwa, wskazując również miejsce zawarcia małżeństwa i formę publiczną, która została zachowana; 9. choćby małżeństwo zostało przygotowane przez kapłana, który nie jest proboszczem strony katolickiej, niemniej jednak proboszcz strony katolickiej pozostaje odpowiedzialny za dopilnowanie uzyskania dyspensy i rejestrację małżeństwa po jego zawarciu"30.

Trzeba zauważyć, że przepisy biskupów kanadyjskich są bardziej szczegółowe, niż odpowiadające im normy biskupów USA. Ważne jest podkreślenie należytego przygotowania do zawarcia małżeństwa mieszanego, za które odpowiedzialni są duszpasterze, szczególnie proboszczowie. Można mieć zastrzeżenia, co do zasadności przyczyny „bliskiej relacji strony niekatolickiej z niekatolickim ministrem” jako

30 Canadian Conference of Catholic Bishops, Complementary norms to the 1983 Code of Canon Law, Dispensation from canonical form of marriage, can. 1127 $\$ 2$, Decree $n r$ 13, Ottawa 1996, s. 93. 
podstawy do udzielenia dyspensy od formy kanonicznej, aczkolwiek można ją tłumaczyć względami ekumenicznymi. Ważne jest, że katalog przyczyn dla dyspensy od formy kanonicznej podany jest jako wyliczenie egzemplarycznie, co daje większą swobodę autorom dyspensy i sprzyja dobru wiernych.

\section{Wnioski}

1. Konferencje Episkopatów Stanów Zjednoczonych i Kanady w zdecydowanej większości wypełniły normy kompetencyjne zawarte w KPK odnośnie do małżeństwa.

2. Wydaje się, że Konferencja Episkopatu Kanady powinna wydać, na wzór Konferencji Biskupów Stanów Zjednoczonych normę, gdzie komunikuje się, że nie zamierza się wydać żadnych norm dotyczących przyrzeczenia małżeństwa, o których traktuje kan. $1062 \$ 1$, jednak bez uszczerbku dla przepisów kanonu $1062 \$ 2$ dotyczących powództwa o naprawienie szkody. Byłoby to formalne wykonanie obligatoryjnej normy kodeksowej.

3. Celowym wydaje się ustanowienie przynajmniej niektórych norm komplementarnych o małżeństwie w sposób ogólny, aby pozostawić pewien margines dla kreatywności normatywnej biskupów diecezjalnych.

4. Wydaje się, że zrezygnowanie z zapowiedzi przedmałżeńskich na poziomie krajowym nie jest zbyt trafne, choć taka możliwość istnieje na żądanie stron, czy na podstawie prawa diecezjalnego, gdyż pozbawia dochodzenie przedmałżeńskie ważnego kryterium weryfikacji stanu wolnego, czy stwierdzenia innych okoliczności, które mogą mieć wpływ na ważność, czy godziwość przyszłego małżeństwa.

5. Ustne składanie przyrzeczenia strony katolickiej w obecności proboszcza lub jego delegata prowadzącego dochodzenie przedślubne przy małżeństwach mieszanych, bez koniecznej obecności świadków nie jest właściwe. Winny być one składane na piśmie, w celu późniejszego ich udowodnienia. 
6. Wydaje się, że właściwym jest podniesienie wieku do godziwego zawarcia małżeństwa według przepisów prawa świeckiego.

7. Kwestia rejestracji zawartych małżeństw powinna podlegać prawu poszczególnych diecezji.

8. Wydanie norm w sprawie udzielania dyspensy od formy zawarcia małżeństwa (kan. $1127 \$ 2$ norma fakultatywna) powinno uwzględniać ducha ekumenizmu, co dobrze uwydatniają normy promulgowane w tej materii przez Konferencje Episkopatów Stanów Zjednoczonych i Kanady.

\section{Complementary norms to the 1983 Code of Canon Law in matrimonial matters issued by the Episcopal Conferences of the United States and Canada \\ Summary}

The purpose of the article is to present Complementary norms to the 1983 Code of Canon Law in respect of matrimonial matters issued by the Episcopal Conferences of the United States and Canada. The author cites and assesses individual complementary norms issued by these fora. Obligatory standards are discussed first, and next optional norms are analysed. The article ends with conclusions and references.

Słowa klucze: Kodeks prawa kanonicznego, normy komplementarne, prawo partykularne, małżeństwo, konferencja episkopatu

Key words: Code of Canon Law, complementary norms, particular law, marriage, episcopal conference, particular law, marriage, episcopal conference

\section{Nota o autorze}

Ks. Jerzy Adamczyk - kapłan diecezji płockiej, doktor habilitowany prawa kanonicznego, wykładowca Wyższego Seminarium Duchownego w Radomiu. 